\title{
Development and Evaluation of a Power Tiller Operated Plastic Mulch Laying Machine
}

\author{
A. Tripathy, P. L. Pradhan*, D. Behera and P. K. Sahoo \\ College of Agricultural Engineering \& Technology, OUAT, \\ Bhubaneswar-751003, Odisha, India \\ *Corresponding author
}

\section{A B S T R A C T}

\section{Keywords \\ Power tiller, mulch laying machine, plastic mulch}

Article Info

Accepted:

18 May 2020

Available Online:

10 June 2020
A power tiller operated plastic mulch laying machine was developed for laying of plastic mulch for different vegetable crops. The machine components are plastic roll carrier unit, press wheel, soil covering unit, bed former and hitching unit which are attached to the main frame of the machine. The developed machine was evaluated at three different speeds of operation and at three different depths of operation of soil covering device. From the field evaluation, it was concluded that $1.5 \mathrm{~km} / \mathrm{h}$ speed of operation at $12 \mathrm{~cm}$ depth of operation was optimum for the machine performance. The optimum values of width of soil cover, thickness of soil cover, bed width and bed height were found to be $18.80 \mathrm{~cm}, 3.10$ $\mathrm{cm}, 50.16 \mathrm{~cm}$ and $10.44 \mathrm{~cm}$, respectively. Draft and power requirement of the machine were found to be $0.7284 \mathrm{kN}$ and $0.3035 \mathrm{~kW}$, respectively. The field capacity and field efficiency were found to be $0.1058 \mathrm{ha} / \mathrm{h}$ and $70.53 \%$. Cost of operation of the power tiller operated plastic mulch laying machine was calculated to be Rs 3781/ha, as compared to Rs 12600/ha in case of manual mulch laying. The payback period of the power tiller along with the plastic mulch laying machine was found to be 1.127 year.The power tiller operated plastic mulch laying machine can be effectively used by the farmers for vegetable cultivation.

\section{Introduction}

Mulch is a layer of material applied to the surface of soil to make favourable environment for plant growth and to increase the crop production. Mulching is basically a protective covering which is made up of organic matters (Organic mulch) like leaves, straw or peat placed around plants, which helps in preventing the moisture to be evaporated, freezing of the roots and growth of weeds (Barche and Nair, 2014). The use of plastic mulch in agriculture has been increased dramatically in the last 10 years throughout the world.

This increase is due to the benefits such as increase in soil temperature, effective weed management, moisture conservation, reduction of certain insect pest, high crop yield, less crop contamination, less soil compaction and improved germination rate 
and more efficient use of soil nutrients (Gowd and Prasad, 2017). When plastic sheet is used as mulch, then it is known as inorganic mulch. Now a days mostly inorganic mulches are used as it is easily available in different thickness and colour (Magdum et al., 2017).

Total area under vegetable crops in Odisha state of India was recorded to be 677000 ha in the year 2013-14 with a production of 9425210 MT (Odisha Agriculture Statistics, 2013-14). Odisha is the leading state in vegetable production in India and the area under plasticulture is increasing day by day in the state. Plastic mulching is used in an area of 5000 ha per year for vegetable production in Odisha. Plastic sheets are laid manually in field where the soil is well prepared to a depth of 15 to $20 \mathrm{~cm}$ (deep ploughing). Field preparation includes one operation of tractor operated mould board plough followed by two operation of tractor drawn rotavator. Manual mulch laying process is characterised with poor quality of work, disturbance of mulch sheet due to wind, labour intensive, mulch sheet getting torn down during handling and difficulty in covering of mulch sheet. Presently, six manual labours are required for laying plastic mulch sheet (Magdum et al., 2017). Manual mulch laying process is time consuming leading to high cost of operation. Tractor operated machines are not much suitable for Odisha condition as the individual plot size is small. Power tillers are very much popular among small and marginal farmers of Odisha (Odisha Agriculture Statistics, Directorate of agriculture and food production, Odisha: from 2006-07 to 2015-16). Previously power tillers were only used for rota-tilling operation, after which they were remaining idle throughout the year. To increase the annual use of power tiller, nowadays it is engaged in various operations like water lifting, puddling, potato planting, drilling of seeds, operating axial flow thresher etc. Hence, a power tiller operated plastic mulch laying machine which is simple in design, affordable and suitable for small field size will meet the need of the farmers growing vegetable and horticultural crops. It will also improve the annual use of power tiller making it more economical to own. Keeping in view the above facts, the present study was undertaken to develop and evaluate a power tiller operated plastic mulch laying machine.

\section{Materials and Methods}

Design consideration for development of power tiller operated plastic mulch laying machine

The power tiller operated plastic mulch laying machine was developed by considering the following functional and economical requirements:

It should be able to lay plastic mulch for different sizes of bed.

Width of mulch laying should be adjustable.

The mulch film should be pressed on the soil bed with the help of press wheel, so that it remains firm.

There should be provision of soil covering device to cover the plastic mulch with soil on both side edges.

The material of construction of different components should be easily and locally available.

The cost of the mulch laying machine should be low, so that small farmers can afford to purchase the machine.

\section{Fabrication of power tiller operated plastic mulch laying machine}

The development of mulch laying machine depends largely upon quality of material and method of fabrication. Very simple and easy method of operation and adjustments were provided so that farmers can use it without 
much skill and knowledge. A prototype power tiller operated plastic mulch laying machine was designed, developed and fabricated at the College of Agricultural engineering \& Technology, Odisha University of Agriculture and Technology, Bhubaneswar, Odisha. The power tiller operated plastic mulch laying machine was made up of the following components.

\section{Main frame}

Main frame was made up of M.S. Square pipe of $(50 \times 50) \mathrm{mm}$ section. The main frame of the machine must be as light as possible to reduce cost, soil compaction and power requirement but strong enough to resist the shocks due to rough fields or obstacles. The overall dimensions of the main frame were $1397 \mathrm{~mm}$ in length, $1524 \mathrm{~mm}$ in width and $635 \mathrm{~mm}$ above the ground level. All parts of machine like hitching unit, press wheel assembly, plastic roll carrier unit and soil covering unit were mounted on the main frame by welding or by using nuts and bolts. A seat was mounted on the top of the frame. Dimensions of seat were 305 x 454 x $300 \mathrm{~mm}$ (L X W XH). Seat dimensions conform to the anthropometric data of the workers of Odisha.

\section{Plastic roll carrier unit}

The plastic roll is carried by a horizontal shaft perpendicular to the direction of travel. The horizontal shaft was mounted at the lower side of the main frame. The plastic sheet has to be placed under the press wheel assembly manually before starting of the plastic mulch laying operation. Length and diameter of plastic roll carrier unit were $1270 \mathrm{~mm}$ and $25 \mathrm{~mm}$ respectively.

\section{Press wheel assembly}

The operation of press wheel is to stretch the laid plastic mulch film on bed so that it does not get displaced while in operation. Two press wheels were provided behind the plastic roll carrier unit. Pneumatic wheels of size (4$8,6 \mathrm{PR}$ ) was used as press wheels. The rim diameter and sectional width of the press wheel was $203 \mathrm{~mm}$ and $102 \mathrm{~mm}$ respectively. Center to center distance between the two press wheel was $614 \mathrm{~mm}$. Press wheel height can be adjusted by adjusting the depth controller.

\section{Soil covering unit}

Soil covering unit was attached to the frame for lifting, turning and throwing the soil over the plastic mulch at the side edges. Two concave discs were used as soil covering unit. Diameter of each disc was $368 \mathrm{~mm}$. The depth of operation of the soil covering device was adjustable. The diameter of the disc was calculated by using following formula as suggested by (Sharma and Mukesh, 2013).

Diameter of disc $\left(\mathrm{D}_{\mathrm{d}}\right)=\frac{\frac{K \times d p}{\cos \beta}}{\mathrm{cm}}$

$\mathrm{K}=$ Coefficient (ranges 2.5-3 for deep tilling. Let's take $3 \mathrm{~cm}$ )

$\mathrm{dp}=$ Depth of ploughing, $\mathrm{cm}\{$ Varies from 10 to $20 \mathrm{~cm}$ \}

$\beta=$ Tilt angle of disc with vertical (Varies from $15^{0}-25^{0}$. Let's take maximum tilt angle of $25^{0}$ )

The value of $D_{d}$ was calculated taking the depth of operation as 10 to $15 \mathrm{~cm}$ as three levels i.e. $10 \mathrm{~cm}, 12 \mathrm{~cm}$ and $14 \mathrm{~cm}$ depth of operation of soil covering device was selected.

So, $D_{d}$ (for $10 \mathrm{~cm}$ depth of ploughing) $=\frac{3 \times 10}{\cos 25}$

$=33.1 \mathrm{~cm}=331 \mathrm{~mm}$

Similarly, $\mathrm{D}_{\mathrm{d}}$ (for $15 \mathrm{~cm}$ depth of ploughing) 
$=\frac{3 \times 15}{\cos 25}=49.6 \mathrm{~cm}=496 \mathrm{~mm}$

So, the diameter of disc varies from $331 \mathrm{~mm}$ to $496 \mathrm{~mm}$. Here diameter of disc was taken as $368 \mathrm{~mm}$.

Thickness of disc $=\mathrm{Td}$

$=0.008 \mathrm{Dd}+1($ Sharma and Mukesh, 2013)

$=0.008 \times 368+1$

$=3.944 \approx 4 \mathrm{~mm}$

So, the thickness of disc $=4 \mathrm{~mm}$.

\section{Bed former}

Bed former was mounted at the front end of the main frame which gathers the soil from the side and forms a bed which can be adjusted according to the requirement of bed width. Its length was $297 \mathrm{~mm}$, width was $64 \mathrm{~mm}$ and height was $190 \mathrm{~mm}$. It was made up of mild steel sheet.

\section{Hitching unit}

Hitching unit was provided to attach the mulch laying machine to the power tiller. It was fixed on the front end of the frame and the machine was attached to the power tiller at the hitch bracket by using a hitch pin. Overall dimension of the hitching unit was $240 \times 60 \times 75 \mathrm{~mm}(\mathrm{~L} \times \mathrm{W} \times \mathrm{H})$.

The inside diameter of the hitching bush was $20 \mathrm{~mm}$. The hitch height from the ground was fixed at $505 \mathrm{~mm}$. Isometric view of the power tiller operated plastic mulch laying machine was made in CATIA Software (Fig. 1) and actual fabricated view of developed power tiller operated plastic mulch laying machine is shown in Fig. 3.

\section{Experimental parameters for field evaluation of the machine}

The machine was evaluated at three speeds of operations were taken. The average speed of power tiller varies between $1.5 \mathrm{~km} / \mathrm{h}$ to 2.5 $\mathrm{km} / \mathrm{h}$ for different operations (Pradhan et al., 2011). So, three speeds i.e. $1.0 \mathrm{~km} / \mathrm{h}, 1.5$ $\mathrm{km} / \mathrm{h}$ and $2 \mathrm{~km} / \mathrm{h}$ were taken for the study. Depth of operation of soil covering device was taken at three levels i.e. $10 \mathrm{~cm}, 12 \mathrm{~cm}$ and $14 \mathrm{~cm}$. Purpose of soil cover is to fix the plastic sheet with the soil so that it is not displaced by rain and wind. At higher depth of operation more soil will be thrown over the plastic sheet which will reduce the exposed area of plastic sheet. As this is not desirable for mulching purpose, the above mentioned depths of operation were taken for the study.

\section{Soil physical properties}

The physical properties of the soil of the experimental field are given bellow:

Type of soil: Sandy loam

Moisture content of soil: $15.00 \%$

Bulk density of soil: $1.33 \mathrm{~g} / \mathrm{cc}$

Performance evaluation of power tiller operated plastic mulch laying machine

\section{Draft and power requirement of the machine}

Draft is defined as horizontal component of pull parallel to line of motion. A load cell was used to measure the draft of the power tiller operated plastic mulch laying machine as shown in Fig. 6. Power requirement of the machine (FAO Agricultural service bulletin 110) was calculated using thefollowing formula;

Power $(\mathrm{kW})=$ Draft $(\mathrm{kN}) \times$ Speed $(\mathrm{m} / \mathrm{s})$ 


\section{Wheel slip}

Wheel slip occurs when there is slippage due to load. Wheel slip was computed considering the following formula.

$$
\% \text { of Wheel slip }=\frac{\frac{D n-D I}{D n}}{D} 100
$$

Where,

$\mathrm{D}_{\mathrm{n}}=$ Distance travelled under no load condition, $\mathrm{m}$;

$\mathrm{D}_{\mathrm{l}}=$ Distance travelled under load condition, $\mathrm{m}$;

\section{Width and thickness of soil cover}

The width and thickness of soil covered on each side of plastic sheet was measured by using a measuring scale. Measurement of width of soil cover is shown in Fig. 7.

\section{Height and width of bed}

After the operation of power tiller operated plastic mulch laying machine, the height and width of bed formed by the machine was measured at different locations in the field with the help of measuring scale.Bed width can be adjusted as per requirement and bed height varies from $7 \mathrm{~cm}$ to $14 \mathrm{~cm}$.

\section{Field capacity and field efficiency}

Theoretical field capacity, actual field capacity and field efficiency were calculated using the following formula (Kepner et al., 1987):

$\mathrm{TFC}=\frac{\mathrm{W} \times S}{10}$

Where,

$\mathrm{TFC}=$ Theoretical field capacity, ha/h;

$\mathrm{S}=$ Speed of operation, $\mathrm{km} / \mathrm{h}$;

$\mathrm{W}=$ Theoretical width of implement, $\mathrm{m}$

\section{$\mathrm{AFC}=\stackrel{\mathrm{A}}{=}$}

Where,

$\mathrm{AFC}=$ Actual field capacity, ha/h;

$\mathrm{A}=$ Actual area covered by implement, ha;

$\mathrm{T}=$ Effective time, $\mathrm{h}$

Field efficiency $=\frac{\text { Actual field capacity }}{\text { Theoretical field capacity }}$

Total cost of power tiller operated plastic mulch laying machine includes cost of operation of power tiller and cost of operation of the developed plastic mulch laying machine. It was calculated on the basis of fixed cost and variable cost(Kepner et al., 1987). The payback period was also calculated considering the cost of manual mulch laying operation.

\section{Results and Discussion}

\section{Field performance result}

\section{Effect of speed of operation on width of soil cover}

The effect of speed of operation on width of soil cover at three different depth of operation is shown in Fig. 5 and the observations on width of soil cover at different speeds and depths of operation were presented in Table 1. With increase in speed of operation from 1 $\mathrm{km} / \mathrm{h}$ to $2 \mathrm{~km} / \mathrm{h}$, the width of soil cover decreased from $18.84 \mathrm{~cm}$ to $14.96 \mathrm{~cm}$ at 10 $\mathrm{cm}$ depth of operation. This may be due to the fact that, the machine gets less time to collect and cover soil over the plastic sheet as speed increases. Similarly, for other depths of operation of soil covering device, same trend was observed.

With increase in depth of operation of soil covering device from $10 \mathrm{~cm}$ to $14 \mathrm{~cm}$, the width of soil cover increased from $18.84 \mathrm{~cm}$ to $30.92 \mathrm{~cm}$ at $1 \mathrm{~km} / \mathrm{h}$ speed of operation. 
This may be due to the fact that more quantity of soil was lifted at greater depth of operation of soil covering device. Similarly, for other speeds of operation same trend was obtained.

\section{Effect of speed of operation on thickness of soil cover}

The effect of speed of operation on thickness of soil cover at three different depth of operation is shown in Fig. 6 and the data collected for thickness of soil cover at different speeds and depths of operation were presented in Table 2. With increase in speed of operation from $1 \mathrm{~km} / \mathrm{h}$ to $2 \mathrm{~km} / \mathrm{h}$, the thickness of soil cover decreased from 2.58 $\mathrm{cm}$ to $1.48 \mathrm{~cm}$ at $10 \mathrm{~cm}$ depth of operation.

This may be due to the fact that; the machine gets less time to cover soil over the plastic sheet as speed increases. Also at higher speed machine throws soil rapidly, so thickness of soil cover decreases. Similarly, for other depth of operation of soil covering device same trend was obtained.

With increase in depth of operation of soil covering device from $10 \mathrm{~cm}$ to $14 \mathrm{~cm}$, the thickness of soil cover increased from 2.58 $\mathrm{cm}$ to $5.10 \mathrm{~cm}$ at $1 \mathrm{~km} / \mathrm{h}$ speed of operation. This may be due to lifting of more soil at greater depth as depth of operation of soil covering device increases. Similarly, for other speed of operation same trend was found.

\section{Effect of speed of operation on bed width and bed height}

The effect of speed of operation on bed width and bed height at three different depths of operation is shown in Fig. 7 and Fig. 8. The observations on bed width and bed height at different speeds and depths of operation were presented in Table 4 and Table 5 respectively. With increase in speed of operation from 1 $\mathrm{km} / \mathrm{h}$ to $2 \mathrm{~km} / \mathrm{h}$, the bed width decreased from
$49.34 \mathrm{~cm}$ to $46.44 \mathrm{~cm}$ and bed height decreased from $9.62 \mathrm{~cm}$ to $6.86 \mathrm{~cm}$ at $10 \mathrm{~cm}$ depth of operation. This may be due to the fact that; the machine gets less time to gather soil in the field as the speed increases. Similarly, for other depths of operation of soil covering device same trend was obtained.

With increase in depth of operation of soil covering device from $10 \mathrm{~cm}$ to $14 \mathrm{~cm}$, the bed width increased from $49.34 \mathrm{~cm}$ to $54.44 \mathrm{~cm}$ and bed height increased from $9.62 \mathrm{~cm}$ to $14.24 \mathrm{~cm}$ at $1 \mathrm{~km} / \mathrm{h}$ speed of operation. This may be due to more lifting of soil at greater depth as depth of operation of soil covering device increases. Similarly, for other speed of operation same trend was found.

From all the observations taken during field evaluation, it was concluded that the performance of the machine was optimum at $12 \mathrm{~cm}$ depth of operation of soil covering device with speed of operation of $1.5 \mathrm{~km} / \mathrm{h}$. Because width of soil cover, thickness of soil cover, bed width and bed height decreased at higher speed.

When less amount and less width of soil is covered over the plastic sheet, it may be displaced by wind and rain. At lower speed more amount of soil was covered over the plastic sheet at lower depth. With increase in depth, there was increase in amount of soil cover over the plastic sheet which is not desirable.

The function of soil covered over sheet is to fix the sheet in proper position and to avoid the sheet to be blown away by wind and rain. So, $1.5 \mathrm{~km} / \mathrm{h}$ speed of operation at $12 \mathrm{~cm}$ depth of operation was found to be optimum for all the dependent parameters. Draft requirement of the machine was calculated at different depth of operation considering this speed of operation. 
Table.1 Width of soil cover at three different speed and depth of operation

\begin{tabular}{|c|c|c|c|c|}
\hline Sl No. & $\begin{array}{c}\text { Speed of operation, } \mathbf{k m} / \mathbf{h} \rightarrow \\
\text { Depth of operation of soil } \\
\text { covering device, } \mathbf{c m} \downarrow\end{array}$ & $\mathbf{1}$ & $\mathbf{1}$ & $\mathbf{2}$ \\
\hline $\mathbf{1}$ & 10 & 18.84 & 16.20 & 14.96 \\
\hline $\mathbf{2}$ & 12 & 22.80 & 18.80 & 15.32 \\
\hline $\mathbf{3}$ & 14 & 30.92 & 24.40 & 19.28 \\
\hline
\end{tabular}

Table.2 Thickness of soil cover at three different speed and depth of operation

\begin{tabular}{|c|c|c|c|c|}
\hline SI No. & $\begin{array}{c}\text { Speed of operation, } \mathbf{~ k m} / \mathbf{h} \rightarrow \\
\text { Depth of operation of soil } \\
\text { covering device, } \mathbf{c m} \downarrow\end{array}$ & $\mathbf{1}$ & $\mathbf{1 . 5}$ & $\mathbf{2}$ \\
\hline $\mathbf{1}$ & 10 & 2.58 & 2.26 & 1.48 \\
\hline $\mathbf{2}$ & 12 & 3.56 & 3.10 & 2.06 \\
\hline $\mathbf{3}$ & 14 & 5.10 & 4.46 & 3.38 \\
\hline
\end{tabular}

Table.3 Bed width at three different speed and depth of operation

\begin{tabular}{|c|c|c|c|c|}
\hline SI No. & $\begin{array}{c}\text { Speed of operation, } \mathbf{~ k m} / \mathbf{h} \rightarrow \\
\text { Depth of operation of soil } \\
\text { covering device, } \mathbf{c m} \downarrow\end{array}$ & $\mathbf{1}$ & $\mathbf{1 . 5}$ & $\mathbf{2}$ \\
\hline $\mathbf{1}$ & 10 & 49.34 & 47.48 & 46.44 \\
\hline $\mathbf{2}$ & 12 & 50.96 & 50.16 & 48.36 \\
\hline $\mathbf{3}$ & 14 & 54.44 & 52.34 & 49.78 \\
\hline
\end{tabular}

Table.4 Bed height at three different speed and depth of operation

\begin{tabular}{|c|c|c|c|c|}
\hline \multirow{2}{*}{ SI No. } & $\begin{array}{c}\text { Speed of operation, } \mathbf{k m} / \mathbf{h} \rightarrow \\
\text { Depth of operation of soil } \\
\text { covering device, cm } \downarrow\end{array}$ & $\mathbf{1}$ & $\mathbf{1 . 5}$ & $\mathbf{2}$ \\
\hline $\mathbf{1}$ & 10 & 9.62 & 8.12 & 6.86 \\
\hline $\mathbf{2}$ & 12 & 11.02 & 10.44 & 8.52 \\
\hline $\mathbf{3}$ & 14 & 14.24 & 11.66 & 9.92 \\
\hline
\end{tabular}

Table.5 Draft and power requirement of the machine

\begin{tabular}{|c|c|c|c|c|c|}
\hline \multirow{2}{*}{$\begin{array}{r}\text { Sl. } \\
\text { No. }\end{array}$} & \multirow{2}{*}{$\begin{array}{l}\text { Depth of operation } \\
\text { of soil covering } \\
\text { device, } \mathrm{cm}\end{array}$} & \multicolumn{2}{|c|}{ Draft, kN } & \multirow{2}{*}{$\begin{array}{l}\text { Draft of the } \\
\text { machine, } k N\end{array}$} & \multirow{2}{*}{$\begin{array}{c}\text { Power } \\
\text { requirement of } \\
\text { the Machine, } \\
\text { kW }\end{array}$} \\
\hline & & $\begin{array}{c}\text { At load } \\
\text { condition }\end{array}$ & $\begin{array}{l}\text { At no load } \\
\text { condition }\end{array}$ & & \\
\hline 1 & 10 & 0.9898 & \multirow[t]{3}{*}{0.4196} & 0.5702 & 0.2376 \\
\hline 2 & 12 & 1.1480 & & 0.7284 & 0.3035 \\
\hline 3 & 14 & 1.3174 & & 0.8978 & 0.3741 \\
\hline
\end{tabular}




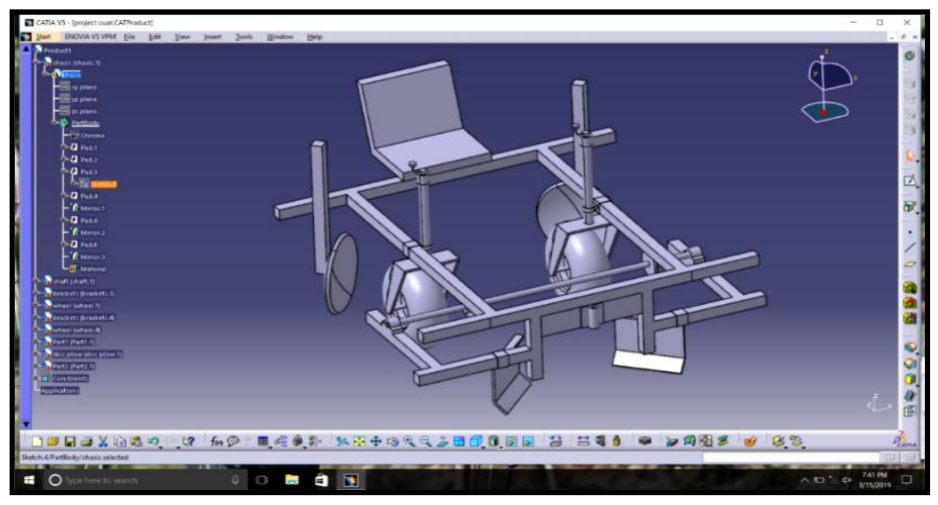

Fig.1 Isometric view of power tiller operated plastic mulch laying machine

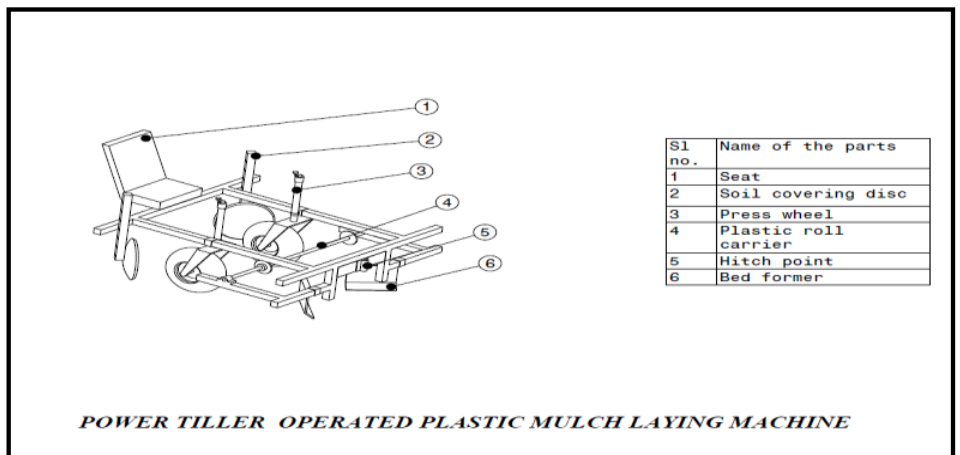

Fig.2 Power tiller operated plastic mulch laying machine indicating all components

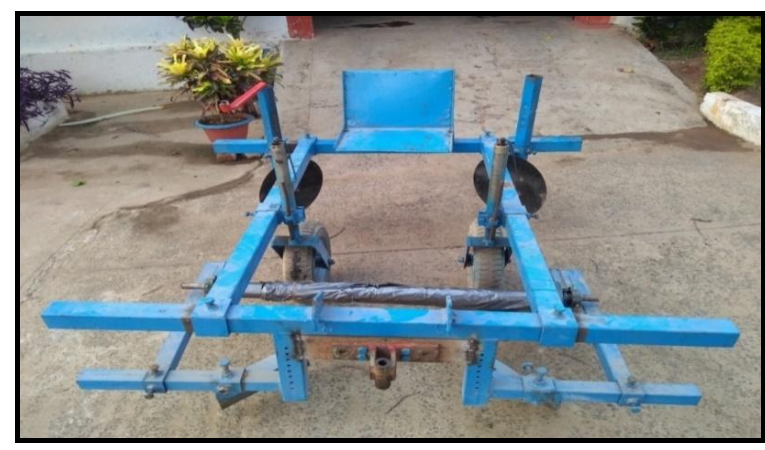

Fig.3 Developed Power tiller operated plastic mulch laying machine

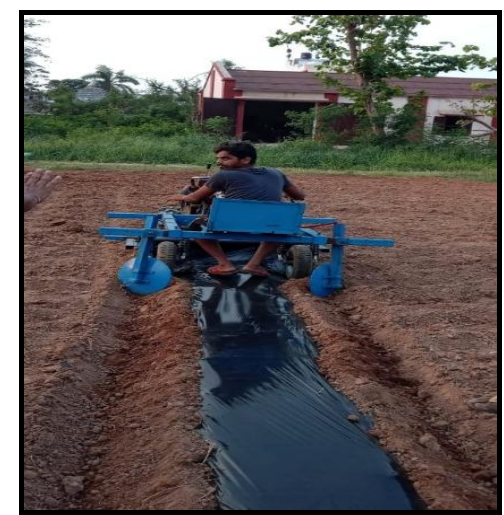

Fig.4 Field testing of power tiller operated plastic mulch laying machine 


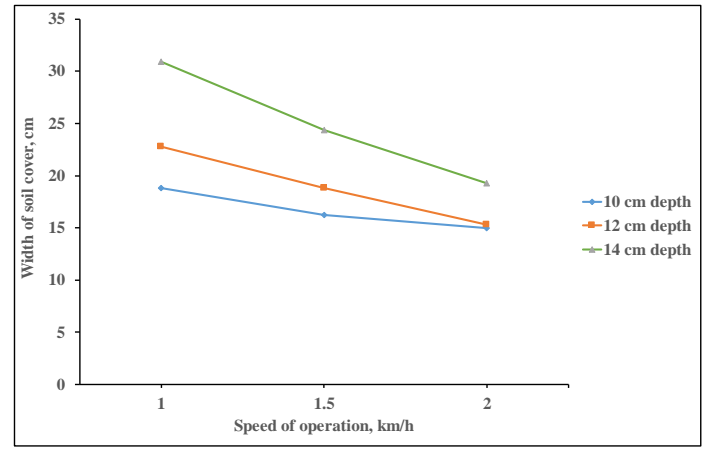

Fig.5 Effect of speed and depth of operation on width of soil cover

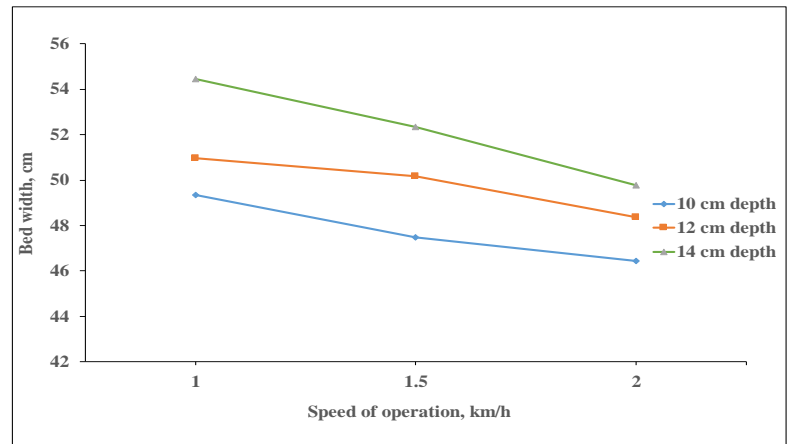

Fig.7 Effect of speed and depth of operation on bed width

Draft and power requirement of the machine

Draft of the machine was calculated at 1.5 $\mathrm{km} / \mathrm{h}$ speed of operation at $12 \mathrm{~cm}$ depth of operation. Draft and power requirement of the machine were found to be $0.7284 \mathrm{kN}$ and $0.3035 \mathrm{~kW}$, respectively. The results of measurement of draft and power requirement of the machine is given in Table5.

Field capacity and field efficiency of the machine

Field capacity and field efficiency were calculated at $1.5 \mathrm{~km} / \mathrm{h}$ speed of operation with depth of operation of soil covering device at $12 \mathrm{~cm}$. The field capacity and field efficiency were found to be $0.1058 \mathrm{ha} / \mathrm{h}$ and $70.53 \%$.

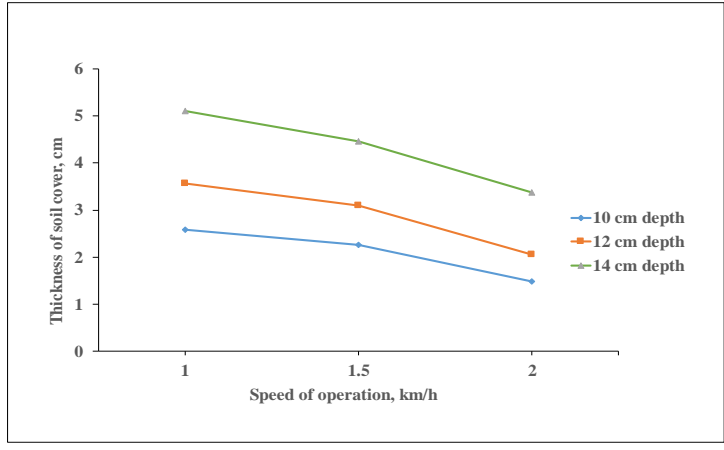

Fig.6 Effect of speed and depth of operation on thickness of soil cover

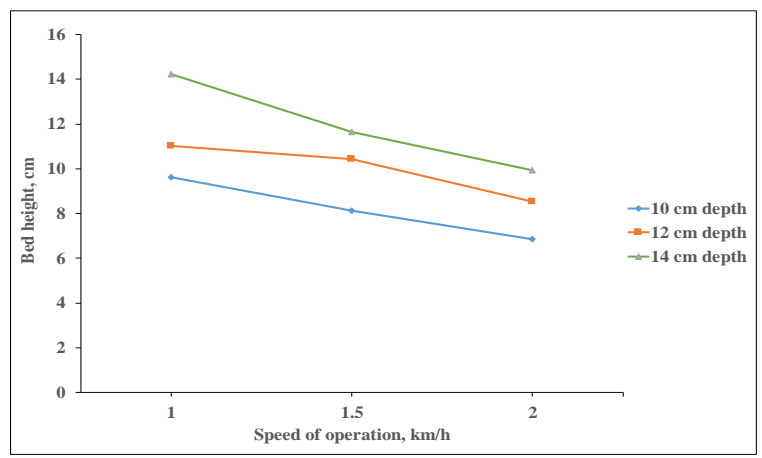

Fig.8 Effect of speed and depth of operation on bed height

\section{Slip}

The number of revolution was fixed to 10 and then the distance covered was measured at load and no load condition was found to be $16.45 \mathrm{~m}$ and $18.50 \mathrm{~m}$ respectively. The slip of the machine was calculated to be $11.08 \%$.

\section{Cost economics}

\section{Cost of operation of power tiller operated plastic mulch laying machine}

The cost of power tiller operated plastic mulch laying machine was based on cost of material and fabrication cost. Cost of materials for fabrication of the machine was estimated based on the prevailing market price. Cost of labour was taken from standard wage rate prescribed by Govt. of Odisha. 
The cost of the power tiller operated plastic mulch laying machine was calculated and found to be Rs 23500/-. Total cost of power tiller operated plastic mulch laying machine includes cost of operation of power tiller and cost of operation of the developed plastic mulch laying machine. The total cost of operation was found to be Rs 400/h.Considering the effective field capacity of $0.1058 \mathrm{ha} / \mathrm{h}$, the cost of operation was found to be Rs 3781/ha.

\section{Comparison of developed plastic mulch laying machine with manually mulch laying method}

Cost of operation of manual mulch laying was estimated to be Rs 12600/ha considering the labour requirement(360 man-h/ha) (Magdum et al., 2017). Hence, there is a saving of Rs $8819 /$ ha by use of power tiller operated plastic mulch laying machine as compared to manual method. Area to be covered by the developed machine to recover purchase price of the machine was 21.47 ha. So, the total number of hours used by the developed mulch laying machine to recover purchase price of the machine was calculated to be 203 hours. Considering the annual use of developed mulch laying machine as $180 \mathrm{~h} /$ year, the initial investment on the cost of power tiller operated plastic mulch laying machine including the cost of power tiller can be recovered with use 1.127 year of operation.

From this study, it was concluded that speed of operation of $1.5 \mathrm{~km} / \mathrm{h}$ at $12 \mathrm{~cm}$ depth of operation was optimum for the machine performance. At this speed and depth of operation; width of soil cover, thickness of soil cover, bed width and bed height were found to be $18.80 \mathrm{~cm}, 3.10 \mathrm{~cm}, 50.16 \mathrm{~cm}$ and $10.44 \mathrm{~cm}$, respectively. Draft and power requirement of the machine were found to be $0.7284 \mathrm{kN}$ (72.84 kgf) and $0.3035 \mathrm{~kW}$ (0.4068 hp), respectively. The actual field capacity and field efficiency were found to be $0.1058 \mathrm{ha} / \mathrm{h}$ and $70.53 \%$. Cost of operation of manual mulch laying was calculated to be Rs $12600 /$ ha, as compared to Rs $3781 /$ ha in case of power tiller operated plastic mulch laying machine. So, there was a saving of Rs 8819/ha in power tiller operated plastic mulch laying machine as compared to manual mulch laying. The payback period of the power tiller along with the plastic mulch laying machine was found to be 1.127 year.Based on the performance results, it was concluded that the power tiller operated plastic mulch laying machine can be efficiently, effectively and economically used by majority of the farmers for vegetable cultivation.

\section{References}

Bainer R; Kepner RA; Barger EL. 1987. Principles of farm machinery. C.B.S. Publishers and distributor, New Delhi.

Gowd CMS; Prasad BD. 2017. Design and development of plastic mulch laying machine in agriculture, IJTIMES, AP, India, 2017; 3(11):97-100.

Magdum SS; Patil SB; Mulla LB. 2017. Automatic mulch paper laying machine for agricultural application, ISSN 2230-9659, 13(01): 241-244.

Marihonnappanavara S; Veerangouda $\mathrm{M}$. 2017. Development and evaluation of tractor operated plastic mulch laying equipment, IJAE, 10(2): 374-378.

Pradhan P; Verma A; Naik R; Guru P. 2015. Traction and drawbar performance characteristics of power tiller attached cage wheel, BIBECHANA13 (2016): 38-49: RCOST.

Pradhan PL; Mishra JN; Paul JC. 2011. Development and Evaluation of a Power Tiller Operated Planter for Maize, AMA, 42(4): 67-71.

Singh AK; Kamal S. 2012. Effect of black plastic mulch on soil temperature and tomato yield in mid hills of Garhwal 
Himalayas, Journal of Horticulture and Forestry vol. 4(4), pp. 78-80.

Singh KG; Sharda RK; Rudra RP; Khan AA. 2014. Mechanization of mulch laying process-A boon in sustaining global agricultural production, 45(4).

Sutar S; Yamgar R; Patil P; Bhosle S; Siddha
UY. 2017. Advanced mulching paper and drip laying machine, IJIR, 3(10): 534-536.

Tipayale A. 2017. Advance mulching paper laying machine, IJSRD - International Journal for Scientific Research \& Development, vol. 5: 2321-0613.

\section{How to cite this article:}

Tripathy, A., P. L. Pradhan, D. Behera and Sahoo. P. K. 2020. Development and Evaluation of a Power Tiller Operated Plastic Mulch Laying Machine. Int.J.Curr.Microbiol.App.Sci. 9(06):

1774-1784. doi: https://doi.org/10.20546/ijcmas.2020.906.221 